\title{
A LOCATION VALUE RESPONSE SURFACE MODEL FOR MASS APPRAISING: AN "ITERATIVE" LOCATION ADJUSTMENT FACTOR IN BARI, ITALY
}

\author{
Maurizio D'AMATO \\ $1^{\text {st }}$ Faculty of Engineering, Technical University - Politecnico di Bari, Via Calefati, \\ 272 - 70122 Bari, Italy \\ E-mail: madamato@interfree.it; Tel.: +39 (0)80 9645267; Fax: +39 (0)80 0999777; Research Web: \\ www.noaves.com; Didactic web: http://mdamato.altervista.org
}

Received 6 June 2009; accepted 20 April 2010

\begin{abstract}
The work is focused on a new model of mass appraising including location variable. A location adjustment factor derived from a mathematical iteration was compared to the location adjustment factor based on geostatistical techniques. The work compares three different linear MRA models. The first one uses the location blind linear MRA. The second integrates the linear MRA with a location adjustment factor calculated using spatial interpolation. The second alternative is an application of Location Value Response Surface Models (O'Connor, 1982). It represents the first application of these models for mass appraising in Italy. The third approach introduces the Iterative Location Adjustment Factor. This is a factor which measure the influence of location derived from a mathematical iteration. Empirical results seem to prove the validity of Iterative Location Adjustment Factors in specific context with few observations.
\end{abstract}

KEYWORDS: Mass appraisal; Automated valuation models; Location; Location value response surface; Location adjustment factor

\section{INTRODUCTION}

Several authors pointed out the role of externalities and location in property values (Krantz et al., 1982; Hoch and Waddell 1993; Des Rosiers et al., 1996). Previous research focused on the problem of variability of house prices which remains unexplained in multiple regression models (Anselin and Can 1986; Dubin 1998). The consequences are for example: the presence of excessive multicollinearity among attributes, spatial autocorrelation among residuals; diminuishing the stability of regression coefficients (Dubin 1988; Anselin and Rey 1991; Des Rosiers and Thériault, 1999). For this reason neighbourhood factors should consider submarket specifics (Adair et al., 1996).
This problem is particularly relevant in real estate markets with a limited number of observations. This work proposes a different approach to location variable in mass appraising and automated valuation modelling. After the application of a traditional location blind MRA linear model, the works compare it with an application of Location Value Response Surface analysis in Italy. It is the first application of this kind of model to the Italian context. The third model derive the location factor from a mathematical iteration instead of geostatistic techniques. The empirical findings of the traditional LAF and the new Iterative Location Adjustment Factor converge on comparable solutions. The article is organized as follows: the first paragraph will give a brief outline of 
Location Value Response Surface Models, in the second paragraph will be proposed the application of an Iterative Location Adjustment Factor for mass appraising. After a comparison among the automated valuation methods applied final remarks will be offered at the end.

\section{LOCATION VALUE RESPONSE SURFACE MODELS}

Location Value Response Surface (LVRS) Analysis has been introduced in US (O'Connor, 1982) for the first time for the appraisal of single family houses in Lucas County, and is different approach to fixed neighbourhoods or composite submarkets analysis (Ward et al., 2002). The application of this method requires spatial interpolation of property prices or error term. This method has been applied in the U.S. (Eichenbaum, 1989; Eichenbaum, 1995; Ward et al., 1999), in England (Gallimore et al., 1996), and Northern Ireland (McCluskey et al., 2000). The application of LVRS allows the appraiser to analyze the effect of location using Geographical Information Systems (GIS). Among different possible classifications it is possible to observe three main approaches to LVRS. A first approach (McCluskey et al., 2000) consists in calculating a location adjustment factor based on the spatial distribution of the selling prices. A price per square metre is obtained dividing the actual price by the gross floor area of the dwelling. A contour plot overlying the area map portrays the peaks and troughs of property values which are also called value influence centres (VICs). In general term the VIC can be defined as point(s), line(s) or area(s) in a contour map where it is possible to observe a relative maximum (positive) or a minimum (negative) location values (errors). As a consequence VIC may affect the value of near properties. Therefore the distance from each VIC is calculated for each observation. The selling price per square meter is regressed on coordinates and the distance of each property to each VIC. The predicted price is then divided by the average estimated price. As a consequence will be determined a local adjustment factor having a mean of 1 . In particular better locations will have a factor greater than 1 , while poorer locations will have a factor less than 1. This local adjustment factor varying from -1 and 1 will become a measure of impact of location in the final regression model whose predictability will be improved. In the case of Bari there is one only VIC and the area is quite homogeneous therefore the measure of distance was the physical distance. A second approach is based on the measure of the variance between actual prices and predicted prices using a MRA model without location variable. This model will present greater value of forecasting error in some areas and lower value in other areas generating a contour map of errors instead of value. Using the error ratio related to under valuation or over valuation and the coordinates of each observation. The impact of each VIC on any property is determined using different possible measures of the distance from the property to the VIC (Eckert, 1990; Eckert et al., 1993). The response surface is depending on the VIC positions and the adopted distance measure. The third approach starts creates an interpolation grid, modelled to reflect the influence on each property of the location ratio factors within its proximity. The method has not been applied to residential flats. It has not been applied outside North America, Britain or Northern Ireland. This is the first application to Italian real estate market. A prerequisite is having sufficient amount of data in each zone of the area considered in order to produce the spatial interpolation. There are not a minimum number of observations but real estate market, especially in the Italian context presents a scarcity of data. Location Adjustment factor does not indicate the value of a certain location, but only the comparative location values for real property 
analysed. Spatial interpolation require the surface of the $z$ variable (selling price or error term) to be continuous and the data value at any location can be estimated if sufficient information about the surface is given. In addition the $z$ variable (selling price or error term) must be spatially dependent therefore the value at any specific location is related to the values of surrounding locations.

\section{THE APPLICATION OF ITERATIVE LOCATION ADJUSTMENT FACTOR IN BARI, ITALY. DATA AND METHODS}

In the residential real estate market of Bari the location factor have been built avoiding the construction of contour maps. In fact in some institutional context it may be not easy to collect data for several problems. In italian context neither real price nor characteristics are always clearly indicated in the transaction and the data are often incomplete. There are few organized databank of real transactions. Developing a Real Estate Market Observatory in order to test and apply mass appraisalautomated valuation models it is not a easy task in Italy. Real Estate Market Observatory founded in 1998 collects real transactions from several sources. It has groups of real estate transactions in several parts of the city of Bari in the south east of Italy. This kind of sample are often recurring in real estate markets without an institutional organization of property data. Although the number of observations are poor this works tries to explore the power of mathematical criterion of minimum square least of representing real estate market contexts like Italy with few data (Kauko and d'Amato, 2008). The work uses a sample of 20 observations in the administrative area of Carrassi Poggiofranco in Bari. These observations are related to residential dwellings in a semicentral location in the urban area of Bari. The list of 20 real observations is indicated in the paragraph 1.1 of the Appendix of this work.
In this work the sample has been analysed considering the following variables indicated in the Table 1.

Table 1. Variable considered in mass appraisal modelling

\begin{tabular}{|c|c|}
\hline PRICE & In Euro \\
\hline DATE & Measured in month \\
\hline ELEVATOR & $\begin{array}{l}\text { Dichotomic variable assuming or not } \\
\text { the presence of an elevator }\end{array}$ \\
\hline BALCONY & Balcony measured in sq.m. \\
\hline SQM & Square meters of the flat \\
\hline
\end{tabular}

The observations are located near an important park of the city of Bari. A first location blind linear multiple regression analysis has been selected among the possible forms to analyse the relationship between the PRICE as dependent variable and the other variables such as BALCONY; ELEVATOR; SQM; and $D A T E$ indicated in the Table 1. The linear model is the following formula (1).

$$
\begin{aligned}
& \text { PRICE }=51.943,42-1545,46 \\
& D A T E+1867,03 S Q M+1547,10 \\
& \text { BALCONY }+37898,76 \text { ELEVATOR }+\varepsilon
\end{aligned}
$$

The paragraph 1.2 of Appendix shows the output of linear regression model. It is possible to observe a good $R^{2}$ equal to 0.89 an acceptable test $\mathrm{F}$ of Fisher, a good performing $\mathrm{t}$ Student Gossett test except for BALCONY variable. The output shows no presence of collinearity. The mean absolute percentage error whose formula is indicated in the formula (2) was calculated in order to test this first regression model.

$$
M A P E=\sum_{i=1}^{n} \frac{\left|\frac{P S_{i}-A S_{i}}{A S_{i}}\right| \cdot 100}{n}
$$

In the formula (2) PS means predicted selling price while $A S$ indicated actual selling 
price, $n$ is the number of observations. The proposed linear regression model has a MAPE of $15,261 \%$. In order to improve the predictability of the model a location adjustment factor was considered in the model. The location of 20 observations in term of longitude and latitude in the area of Bari is indicated in the Table 2.

The geographic distribution of 20 observations in the urban context of Bari is indicated in the Figure 1. In the middle of area it is possible to observe the urban park "Largo 2 Giugno”.
Spatial correlation among the 20 observations was preliminary detected using Moran's I (Moran, 1948; Moran, 1950) test. This index measures autocorrelation between values of the $\mathrm{x}$ vector. It ranges from -1 to +1 and each observation is only compared with its relevant neighbourhood. Positive Moran's I indicates positive autocorrelation which means that high values for $x$ or (market basket value or price per square meters) should be located near other high values while lower market basket values should be located near other lower market basket values.

Table 2. Geographic coordinates of the 20 observations

\begin{tabular}{rlll}
\hline & & LATITUDE (Degrees) & LONGITUDE (Degrees) \\
\hline 1. & Kennedy 1d & 41,100636 & 16,871099 \\
2. & Morea 17 & 41,10471 & 16,86902 \\
3. & Petroni 102d & 41,103909 & 16,867173 \\
4. & De Viti de Marco 20 & 41,105277 & 16,877635 \\
5. & Gabrieli 7 & 41,106387 & 16,872217 \\
6. & Morea 38 & 41,102328 & 16,870263 \\
7. & Kennedy 6 & 41,100607 & 16,870826 \\
8. & Benedetto XIII & 41,103248 & 16,865226 \\
9. & Fanelli 206b & 41,098432 & 16,881172 \\
10. & Fanelli 207 & 41,105981 & 16,878358 \\
11. & Salvemini 68 & 41,102619 & 16,88289 \\
12. & Gabrieli 12 & 41,106418 & 16,872018 \\
13. & Podgora & 41,105277 & 16,8709 \\
14. & Petroni 91bis & 41,102061 & 16,867097 \\
15. & Pavoncelli & 41,104203 & 16,877291 \\
16. & via Podgora 83 & 41,10536 & 16,869171 \\
17. & via A. De Gasperi 401 & 41,098898 & 16,871173 \\
18. & v.le Resistenza 108 & 41,104311 & 16,875363 \\
19. & via lacini 5 & 41,104854 & 16,878576 \\
20. & via D. D’Orso 14 & 41,103131 & 16,880158 \\
\hline
\end{tabular}




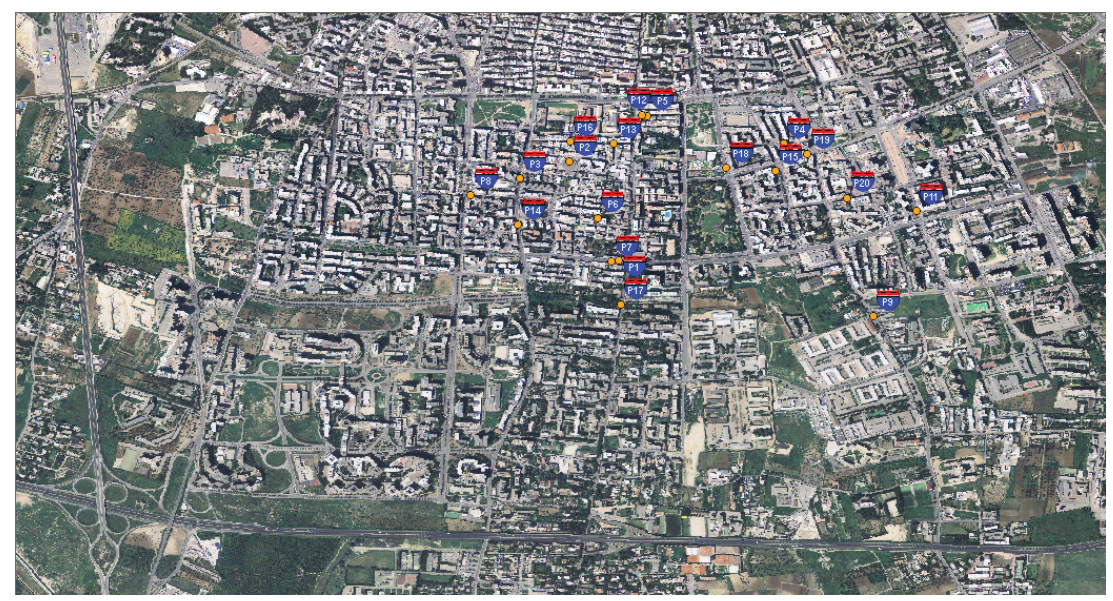

Figure 1. Map of observations

A significantly negative Moran's I implies spatial heterogeneity, or that high values are near low, or vice versa. Moran's test formula is indicated in the formula (3).

$$
I=\frac{N \sum_{i=1}^{n} \sum_{j=1}^{n} w_{i j}\left(x_{i}-\bar{x}\right)\left(x_{j}-\bar{x}\right)}{\sum_{i=1}^{n} \sum_{j=1}^{n} w_{i j}\left(x_{i}-\bar{x}\right)^{2}}
$$

where: $x$ is the variable (the market basket value), and $w_{i j}$ represents the set of neighbours $j$ for observation $i$.

In this case, as in previous examples in literature, inverse squared distance among the observations has been considered (Des Rosiers and Thériault, 1999) The final result showed positive autocorrelation assuming a value of 0,7954 . A market basket value (say price per unit) has been calculated in order to produce a contour map. Contour map is a map created joining all the points having similar measure (similar price per square meter). The market basket value has been obtained dividing the actual property price by the square meters. In the following Figure 2 is indicated the contour map.

Starting from the spatial distribution of the market basket value it has been possible to

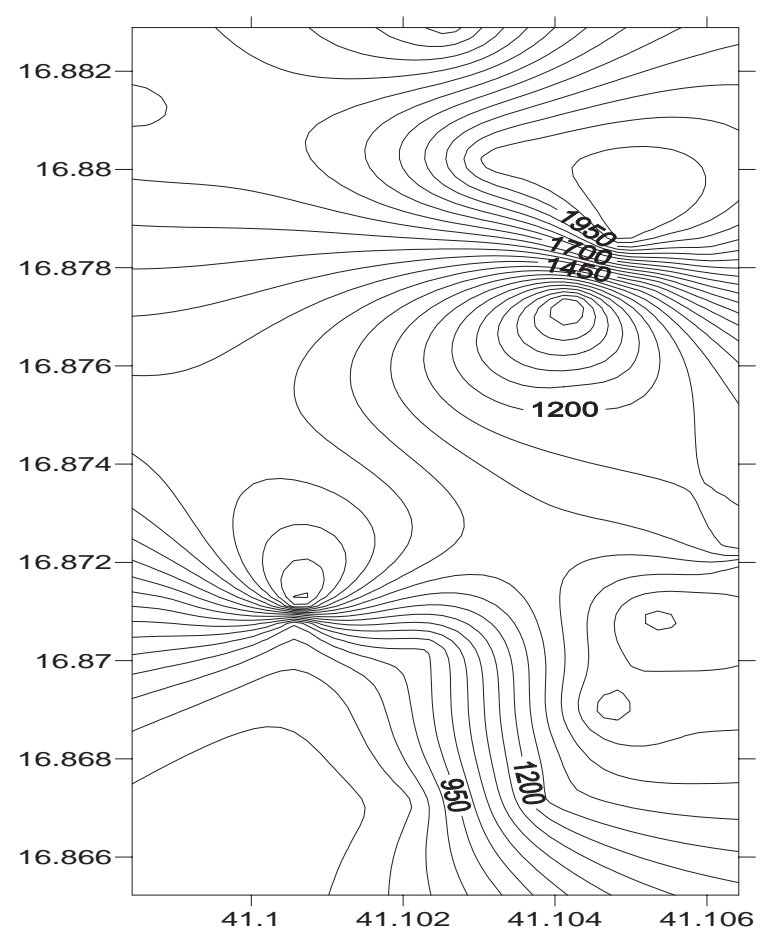

Figure 2. Contour map of market basket

observe the relationship between the price per unit of observations and their location through a linear semivariogram. The surface obtained allowed the application of an universal kriging to generate a surface in order to model 
location variable in this residential property market. Kriging is a spatial interpolation technique which relies on analysis of the spatial variance of a phenomenon. Spatial variability is used to build experimental variogram and observe means differentials between values. In this application the "regional" variable is the price per square meter (Cressie, 1993). Variograms are then formally approximated with a formal function. In this case the theoretical function is linear to obtain the best adjustment for value variations resulting from proximity. The universal kriging was carried out using SURFER 8.

Therefore a second MRA has been runned considering the value influence center clearly individuated in the kriging whose coordinates are indicated in the Table 3.

Table 3. Coordinates of Location Adjustment Factor

\begin{tabular}{ll}
\hline LATITUDE & LONGITUDE \\
\hline 41,1063629 & 16,88000012 \\
\hline
\end{tabular}

This second linear regression model includes the physical distance between each point and the VIC previsously individuated in the Table 3 in the variable LAF or Location Adjustement Factor. In the paragraph 1.3 of Appendix is indicated the formula of physical distance between the coordinates of two points. The second regression model indicated in the formula (4).

$$
\begin{aligned}
& \text { PRICE }=112290,19-1524,46 \\
& D A T E+1567,08 S Q M+1463,55 \\
& \text { BALCONY }+42204,36 \text { ELEVATOR + } \\
& 51112,55 L A F+\varepsilon
\end{aligned}
$$

The output of this regression model is indicated in the paragraph 1.4 of Appendix. The $\mathrm{R}^{2}$ is 0.93 , the $\mathrm{F}$ di Fisher test and the t-test of Student Gossett are both satisfying. The mean absolute percentage error is 11.08 with a significative improvement compared to the first MRA model presented in the formula (1).

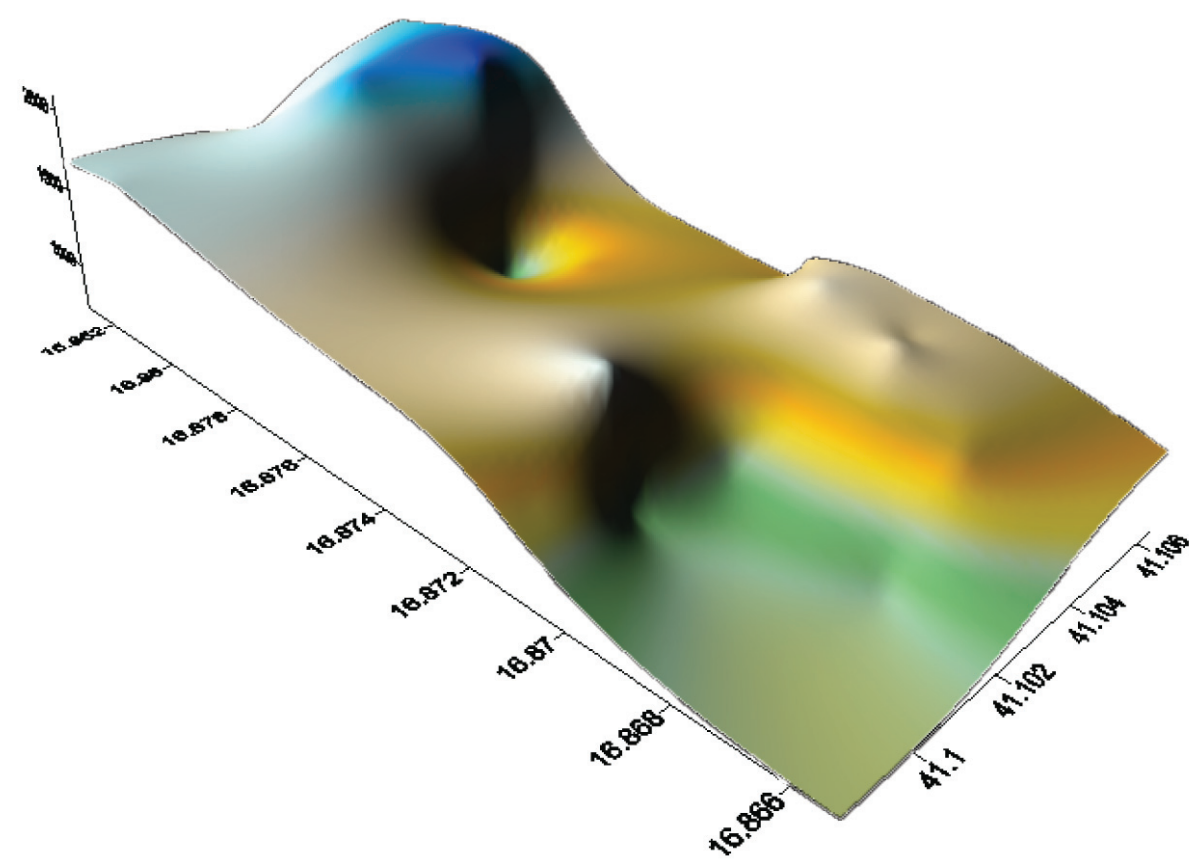

Figure 3. Universal kriging calculated on the Market Basket Value 
This work proposed the research of a location adjustment factor without using geostatistical tehnique. For this reason a third linear regression model has been applied to the same sample of 20 observations selected in this work. The MRA model is indicated in the following formula (5).

$$
\begin{aligned}
& \text { PRICE }=\text { CONSTANT }+X_{1} \text { DATE }+ \\
& X_{2} S U I+X_{3} \text { BALCONY }+X_{4} E L E V A T O R+ \\
& X_{5} I L A F+\varepsilon
\end{aligned}
$$

The formula (5) has the same variables of formula (4) except for a new variable indicated as ILAF (Iterative Location Adjustment Factor) instead of LAF (Location Adjustment factor). This variable is the physical distance in $\mathrm{km}$ of the coordinates (longitude and latitude) of each point from a virtual point whose coordinates should be defined after a mathematical non linear iteration in order to reach the highest level of $R^{2}$. In the Appendix paragraph 1.3 is indicated the formula. After several iterations carried out through the command "Excel Solver" it has been possible to define an Iterative Location Adjustment Factor. It is Iterative because it is simply based on non linear iterations. The coordinates of this point (for this study we call it iterative location adjustment point) will varies in a mathematical iteration in order to select the appropriate Iterative Location Adjustment Factor. At this stage using solver command of Excel it is assumed the following goal function indicated in formula (6).

$$
\max f(x) ; \max R^{2}
$$

where: $\mathrm{R}^{2}$ is the well known coefficient of determination.

The constraints will regard the coordinates of the iterative location adjustment point. It will vary according to these contraints that must be applied to the coordinates. The value of these constraints are indicated in the Table 4.
Table 4. Constraints for iterative location adjustment factor point selection

\begin{tabular}{lll}
\hline $\begin{array}{l}\text { Constraints for } \\
\text { iterative location } \\
\begin{array}{l}\text { adjustment } \\
\text { factor point } \\
\text { selection }\end{array}\end{array}$ & LATITUDE & LONGITUDE \\
\hline $\min$ & 41,098432 & 16,865226 \\
$\max$ & 41,106418 & 16,88289 \\
\hline
\end{tabular}

In this way the virtual point to be individuated through non linear iterations is inside the area individuated by the coordinates of the points. Several iterations were carried out using the simple function Solver included in the well known MS Office Excel. The iterations selected an Iterative location Adjustment Point as VIC without using geostatistics techniques. The report of iterations is indicated in the Appendix with the paragraph 1.4. The iterative locatin adjustment factor has the coordinates indicated in the Table 5.

Table 5. Coordinates of iterative value influence center

\begin{tabular}{lcc}
\hline & LATITUDE & LONGITUDE \\
\hline $\begin{array}{l}\text { ITERATIVE } \\
\text { value influence } \\
\text { center }\end{array}$ & 41,106418 & 16,88289 \\
\hline
\end{tabular}

Therefore a third linear regression model was runned considering the same variable of model 4. In this model the term ILAF - Iterative Location Adjustment Factor indicates the distance among each point of the sample and the coordinates of the Iterative Value Influence Center indicated in the Table 5. The formula (7) shows the linear multiple regression model obtained.

$$
\begin{aligned}
& \text { PRICE }=52.992,393-1528,46 \\
& D A T E+1495,12 S Q M+1763,11 \\
& \text { BALCONY }+36874,73 \text { ELEVATOR }+ \\
& 38093,64 I L A F+\varepsilon
\end{aligned}
$$


The model indicated in the formula 6 is linear having the same characteristics of the model indicated in the formula (4). The variable ILAF has a positive marginal price. The t-student Gossett test of ILAF variable shows a satisfying a 3.429. The iteration indicated an undesired place near a crossroad with problem of traffic, noise and pollution. This is the reason why the marginal is positive. The unpleasent place can be easily individuated in the kriging of market basket value in the Figure 3. It is worth to notice the convergence between empirical findings of kriging technique and the iterations proposed. In the Appendix paragraph 1.5 are indicated the statistics of this third regression containing ILAF - Iterative Location Adjustment Factor. The $\mathrm{R}^{2}$ is 94.0 the Fisher and the t-student Gossett tests are encouraging. The mean absolute percentage error is equal to 11.07 . It presents a small improvement compared to the first model and to the second - Location Value Response Surface Model. The final Table 6 compares the three mass appraising models.

Table 6. Final comparison among the three regression models

\begin{tabular}{llll}
\hline & $\begin{array}{l}\text { I. Model } \\
\text { location } \\
\text { blind linear } \\
\text { MRA }\end{array}$ & $\begin{array}{l}\text { II. Model } \\
\text { MRA } \\
\text { integrated } \\
\text { with LAF }\end{array}$ & $\begin{array}{l}\text { III. Model } \\
\text { MRA } \\
\text { integrated } \\
\text { with ILAF }\end{array}$ \\
\hline$R^{2}$ & 0,89 & 0,93 & 0,94 \\
MAPE & 15,26 & 11,08 & 11,07 \\
\hline
\end{tabular}

The comparison seems to confirm that the Iterative Location Adjustment Factor may represent an interesting tool to develop for implementing Mass Appraisal and Automated Valuation Systems.

\section{FINAL REMARKS AND FUTURE DIRECTIONS OF RESEARCH}

The works demonstrated that it is possble to produce an Iterative Location Adjustment Factor using a mathematical iteration instead of the well known geostatistical techniques. Among three different models the Iterative Location Adjustment Factor based on mathematical modelling showed and interesting performance. The iteration were carried out with a quite simple software like MS Office Excel using solver function. More complex analysis with more than one or two VICs may require the use of MathLab or Solver programming offered by Frontline. Further researches may verify the Iterative Location Adjustment Factor in area with more than one VIC and with different formal function from the linear one.

\section{REFERENCES}

Adair, A. S., Berry, J. N. and McGreal, S. W. (1996) Hedonic modelling, housing submarkets and residential valuation, Journal of Property Research, 13(1), pp. 67-83. doi:10.1080/095999196368899

Anselin, L. and Can, A. (1986) Model comparison and model validation issues in empirical work on urban density functions, Geographical Analysis, 18, pp. 179-197.

Anselin, L. and Rey, S. (1991) Properties of tests for spatial dependence in linear regression models, Geographical Analysis, 23(2), pp. 112-131.

Cressie, N. (1993) Statistics for spatial data (Wiley series in probability and statistics). Wiley-Interscience, New York.

Des Rosiers, F., Lagana, A., Thériault, M. and Beaudoin, M. (1996) Shopping centres and house values: an empirical investigation, Journal of Property Valuation and Investment, 14(4), pp. 41-62. doi:10.1108/14635789610153461

Des Rosiers, F. and Thériault, M. (1999) House prices and spatial dependence: towards an integrated procedure to model neighborhood dynamics, Working Papers, Laval - Faculte des sciences de administration. 
Dubin, R. A. (1988) Estimation of regression coefficients in the presence of spatially autocorrelated error terms, Review of Economics and Statistics, 70(3), pp. 466-474. doi:10.2307/1926785

Dubin, R. A. (1998) Predicting house prices using multiple listings data, Journal of Real Estate Finance and Economics, 17(1), pp. 35-59. doi:10.1023/A:1007751112669

Eckert, J. (Ed.) (1990) Property appraisal and assessment administration, The International Association of Assessing Officers, Chicago, IL.

Eckert, J., O'Connor, P. and Chamberlain, C. (1993) Computer-assisted real estate appraisal: a California savings and loan case study, The Appraisal Journal, LXI(4), pp. 524-532.

Eichenbaum, J. (1989) Incorporating Location into Computer-Assisted Valuation, Property Tax Journal, 8(2), pp. 151-169.

Eichenbaum, J. (1995) The location variable in world class cities: lessons from cama valuation in New York city, Journal of Property Tax Assessment and Administration, 1(3), pp. 46-60.

Gallimore, P., Fletcher, M. and Carter, M. (1996) Modelling the influence of location on value, Journal of Property Valuation and Investment, 14(1), pp. 6-19. doi:10.1108/14635789610107444

Hoch, I. and Waddell, P. (1993) Apartment rents: another challenge to the monocentric model, Geographical Analysis, 25(1), pp. 20-34.

Kauko, T. and d'Amato, M. (2008) Mass appraising. An international perspective for property valuers, Wiley Blackwell, London.
Krantz, D. P., Weaver, R. D. and Alter, T. R. (1982) Residential property tax capitalization: consistent estimates using micro-level data, Land Economics, 58(4), pp. 488-496. doi:10.2307/3145695

Moran, P. A. P. (1948) The interpretation of statistical maps, Journal of the Royal Statistical Society Series B-Statistical Methodology, 10, pp. 243-251.

Moran, P. A. P. (1950) Notes on continuous stochastic phenomena, Biometrika, 37(1-2), pp. 17-23. doi:10.1093/biomet/37.1-2.17

McCluskey, W. J., Deddis, W. G., Lamont, I. G. and Borst, R. A. (2000) The application of surface generated interpolation models for the prediction of residential property values, Journal of Property Investment and Finance, 18(2), pp. 162-176. doi:10.1108/14635780010324321

O'Connor, P. (1982) Locational valuation derived directly from the real estate market with the assistance of response surface techniques, Lincoln Institute of Land Policy.

Ward, R. D., Weaver, J. R. and German J. C. (1999) Improving models using geographic information systems/response surface analysis location factors, Assessment Journal, 6(1), pp. 30-38.

Ward, R. D., Guilford, J., Jones, B., Pratt, D. and German, J. C. (2002) Piecing together location: three studies by the Lucas County research and development staff, Assessment Journal, 9(5), pp. 15-48.

\section{SANTRAUKA}

\section{GEOGRAFINĖS PADE்TIES VERTĖS STEBIMOJO PAVIRŠIAUS MODELIS MASINIAM TURTO VERTINIMUI: ITERACINIS GEOGRAFINĖS PADE்TIES KOREKCIJOS VEIKSNYS BARYJE (ITALIJA)}

\section{Maurizio D’AMATO}

Darbe nagrinejjamas naujas masinio turto vertinimo modelis, apimantis geografinès padèties kintamaji. Iteraciniu būdu apskaičiuotas geografinès padèties korekcijos veiksnys palygintas su geografinès padèties korekcijos veiksniu, gautu taikant geostatistinius metodus. Darbe lyginami trys skirtingi tiesiniai MRA modeliai. Pirmajame naudojamas geografinès padèties nevertinantis tiesinis MRA. Antrajame tiesinis MRA sujungiamas su geografinès padèties korekcijos veiksniu, apskaičiuotu pasitelkus erdvinę interpoliaciją. Antrojoje alternatyvoje pritaikomi geografinès padèties vertès stebimojo paviršiaus (angl. Location Value Response Surface) modeliai (O'Connor 1982). Italijoje šie modeliai masiniam turto vertinimui naudojami pirmą karta. Trečiojoje alternatyvoje taikomas iteracinis geografinės padèties korekcijos veiksnys. Jis i̇vertina geografinės padèties įtaka, nustatytą iteraciniu būdu. Empiriniai rezultatai, regis, i̇rodo iteraciniu geografinès padèties korekcijos veiksnių pagrisstumą konkrečiame kontekste, kai stebẻjimu yra mažai. 


\section{APPENDIX}

1.1. List of 20 observations, residential real estate transactions in the real estate market of Bari

\begin{tabular}{lllll}
\hline SQM & BALCONY & ELEV & DATE & PRICE \\
\hline 100,00 & 25,00 & 1,00 & 85 & $€ 198.000,00$ \\
65,00 & 1,00 & 78 & $€ 113.620,00$ \\
85,00 & 14,00 & 1,00 & 92 & $€ 123.970,00$ \\
71,00 & 1,00 & 86 & 108 & $€ 110.000,00$ \\
54,00 & 7,90 & 1,00 & 111 & $€ 74.890,00$ \\
90,00 & 9,50 & 1,00 & 103 & $€ 69.720,00$ \\
62,50 & 27,00 & 1,00 & 87 & $€ 74.890,00$ \\
75,00 & 23,00 & 1,00 & 90 & $€ 163.944,06$ \\
90,00 & 6,60 & 1,00 & 64 & $€ 293.000,00$ \\
135,00 & 7,00 & 1,00 & 86 & $€ 201.418,00$ \\
130,00 & 24,00 & 1,00 & 75 & $€ 144.607,93$ \\
95,00 & 10,00 & 1,00 & 62 & $€ 130.000,00$ \\
72,00 & 10,00 & 1,00 & 89 & $€ 65.000,00$ \\
85,00 & 17,00 & 0,00 & 107 & $€ 77.469,00$ \\
75,60 & 0,00 & 0,00 & 75 & $€ 144.608,00$ \\
95,00 & 21,00 & 1,00 & 79 & $€ 103.000,00$ \\
85,00 & 10,00 & 0,00 & 67 & $€ 103.290,00$ \\
85,00 & 9,45 & 0,00 & 62 & $€ 185.000,00$ \\
80,00 & 3,35 & 1,00 & 61 & $€ 260.000,00$ \\
115,00 & 10,00 & 1,00 & &
\end{tabular}

1.2. SPSS ouput regression model on 20 observations in the residential real estate market of Bari

Variables Entered/Remowed
\begin{tabular}{|l|l|l|l|}
\hline Mode & $\begin{array}{l}\text { Variables } \\
\text { Entered }\end{array}$ & \multicolumn{1}{|c|}{$\begin{array}{l}\text { Variables } \\
\text { Removed }\end{array}$} & Method \\
\hline 1 & $\begin{array}{l}\text { SUI, } \\
\text { ELEVATOR, } \\
\text { BALCONY, } \\
\text { DATE }\end{array}$ &. & Enter \\
\hline
\end{tabular}
a. All requested variables entered.
b. Dependent Variable: PRICE

Model Summary

\begin{tabular}{|c|c|c|c|c|}
\hline \multicolumn{5}{|c|}{ Model Summary } \\
\hline Mode & $\mathrm{R}$ & R Square & $\begin{array}{c}\text { Adjusted R } \\
\text { Square }\end{array}$ & $\begin{array}{l}\text { Std. Error of } \\
\text { the Estimate }\end{array}$ \\
\hline 1 & $944^{a}$ & 890 & 861 & 23626,431 \\
\hline
\end{tabular}




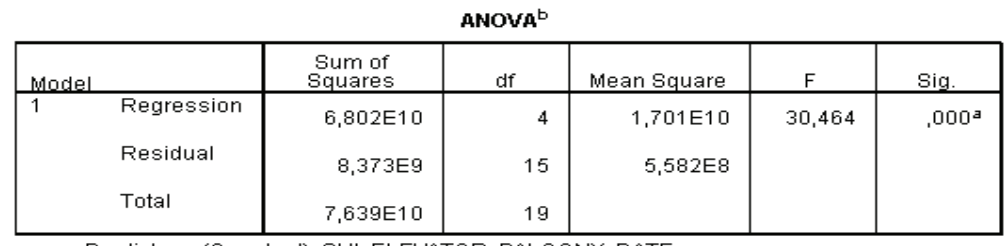

a. Predictors: (Constant), SUI, ELEVATOR, BALCONY, DATE

b. Dependent Variable: PRICE

Coefficients $^{a}$

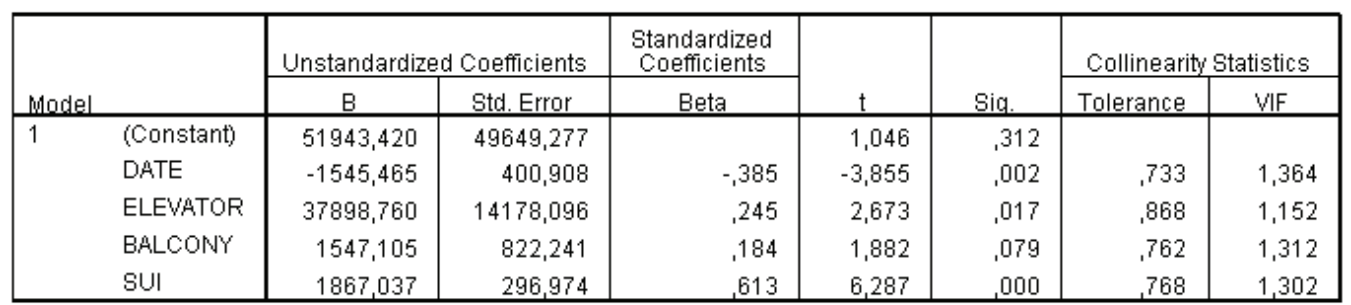

a. Dependent Variable: PRICE

Collinearity Diagnostics ${ }^{a}$

\begin{tabular}{|c|c|c|c|c|c|c|c|c|}
\hline \multirow[b]{2}{*}{ Mode } & \multirow{2}{*}{$\begin{array}{l}\text { Dime } \\
\text { nsio } \\
\text { n }\end{array}$} & \multirow[b]{2}{*}{ Eigenvalue } & \multirow[b]{2}{*}{$\begin{array}{c}\text { Condition } \\
\text { Index }\end{array}$} & \multicolumn{5}{|c|}{ Variance Proportions } \\
\hline & & & & (Constant) & DATE & ELEVATOR & BALCONY & SUI \\
\hline \multirow[t]{5}{*}{1} & 1 & 4,615 & 1,000 &, 00 &, 00 &, 01 & 01 &, 00 \\
\hline & 2 & .174 & 5,155 & ,01 &, 02 &, 15 & .50 &, 02 \\
\hline & 3 &, 146 & 5,628 & 00 &, 01 & .77 &, 39 &, 00 \\
\hline & 4 &, 058 & 8,887 &, 00 &, 17 &, 02 & ,01 &, 39 \\
\hline & 5 & 007 & 25,096 & 99 & 81 & 05 & 10 & 58 \\
\hline
\end{tabular}

a. Dependent Variable: PRICE

Residuals Statistics ${ }^{a}$

\begin{tabular}{|l|r|r|r|r|r|}
\hline & \multicolumn{1}{|c|}{ Minimum } & Maximum & \multicolumn{1}{c|}{ Mean } & Std. Deviation & \multicolumn{1}{c|}{$N$} \\
\hline Predicted Value & 41901,43 & 272453,03 & 136971,35 & 61395,277 & 20 \\
Residual & $-23490,285$ & 32988,566 &, 000 & 15854,262 & 20 \\
Std. Predicted Value & $-1,548$ & 2,207 &, 000 & 1,000 & 20 \\
Std. Residual & $-1,272$ & 1,786 &, 000 &, 858 & 20 \\
\hline
\end{tabular}

a. Dependent Variable: PRICE

\subsection{Physycal distance between two points $A$ and $B$ whose coordinates} are $A\left(a_{1} ; b_{1}\right)$ and $B\left(a_{2} ; b_{2}\right)$

$$
d(A, B)=\left[\arccos \left(\cos \left(a_{1}-a_{2}\right) \cos \left(b_{1}\right) \cos \left(b_{2}\right)+\sin \left(b_{1}\right) \sin \left(b_{2}\right)\right] \times 6360\right.
$$


1.4. SPSS ouput regression model on 20 observations in the residential real estate market of Bari using location adjustment factor based on universal kriging

\begin{tabular}{l} 
Model Summary \\
\begin{tabular}{|l|l|r|r|r|}
\hline $\begin{array}{l}\text { Mode } \\
11\end{array}$ & $\mathrm{R}$ & $\mathrm{R}$ Square & $\begin{array}{c}\text { Adjusted R } \\
\text { Square }\end{array}$ & $\begin{array}{c}\text { Std. Error of } \\
\text { the Estimate }\end{array}$ \\
\hline 1 & $968^{a}$ & 937 & 915 & 18469,657 \\
\hline
\end{tabular} \\
\hline
\end{tabular}

b. Dependent Variable: PRICE

ANOVA ${ }^{\mathrm{b}}$

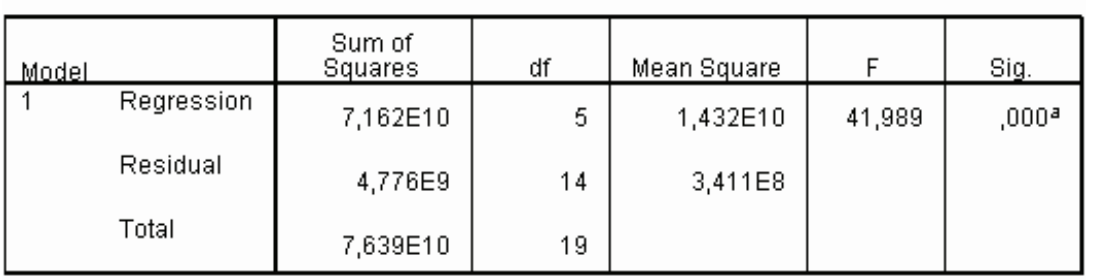

a. Predictors: (Constant), LAF, ELEVATOR, DATE, BALCONY, SUI

b. Dependent Variable: PRICE

Coefficients $^{a}$

\begin{tabular}{|c|c|c|c|c|c|c|c|c|}
\hline \multirow{2}{*}{\multicolumn{2}{|c|}{ Model }} & \multicolumn{2}{|c|}{ Unstandardized Coefficients } & \multirow{2}{*}{$\begin{array}{c}\begin{array}{c}\text { Standardized } \\
\text { Coefficients }\end{array} \\
\text { Beta } \\
\end{array}$} & \multirow[b]{2}{*}{$\mathrm{t}$} & \multirow[b]{2}{*}{ Siq. } & \multicolumn{2}{|c|}{ Collinearity Statistics } \\
\hline & & $\mathrm{B}$ & Std. Error & & & & Tolerance & VIF \\
\hline \multirow[t]{6}{*}{1} & (Constant) & 112290,196 & 43032,118 & & 2,609 & .021 & & \\
\hline & DATE & $-1524,141$ & 313,474 &,- 380 & $-4,862$ & 000 & .733 & 1,365 \\
\hline & ELEVATOR & 42204,362 & 11162,566 &, 273 & 3,781 & ,002 & .856 & 1,169 \\
\hline & BALCONY & 1463,551 & 643,291 &, 174 & 2,275 & ,039 & .761 & 1,314 \\
\hline & SUI & 1567,088 & 249,856 & .515 & 6,272 & ,000 & .663 & 1,509 \\
\hline & LAF & $-51112,559$ & 15739,698 & -240 & $-3,247$ & 006 & 817 & 1,223 \\
\hline
\end{tabular}

a. Dependent Variable: PRICE

Residuals Statistics ${ }^{a}$

\begin{tabular}{|l|r|r|r|r|r|}
\hline & \multicolumn{1}{|c|}{ Minimum } & Maximum & \multicolumn{1}{c|}{ Mean } & Std. Deviation & \multicolumn{1}{c|}{$N$} \\
\hline Predicted Value & 41901,43 & 272453,03 & 136971,35 & 61395,277 & 20 \\
Residual & $-23490,285$ & 32988,566 &, 000 & 15854,262 & 20 \\
Std. Predicted Value & $-1,548$ & 2,207 &, 000 & 1,000 & 20 \\
Std. Residual & $-1,272$ & 1,786 &, 000 &, 858 & 20 \\
\hline
\end{tabular}

a. Dependent Variable: PRICE 


\subsection{Excel report on iteration - iterative location adjustment point calculation}

Micros oft Excel 11.0 Rapporto valori

Data di creazione: 05/06/2009 20.27.20

Cella obiettivo (Max)

\begin{tabular}{lrrr}
\hline C ella & Nome & Valori orig inali & Valore finale \\
\hline$\$ 1 \$ 41$ & DATE & 0,940471283 & 0,940471283 \\
\hline
\end{tabular}

\begin{tabular}{|c|c|c|c|}
\hline C ella & Nome & Valori orig inali & Valore finale \\
\hline$\$ C \$ 4$ & Parco 2 Giugno LATITUDINE (Deqrees) & 41,10353295 & 41,10353295 \\
\hline$\$ D \$ 4$ & Parco 2 Giugno LONGTUDINE (Degrees) & 16,865226 & 16,865226 \\
\hline
\end{tabular}

\begin{tabular}{|c|c|c|c|c|c|}
\hline \multicolumn{6}{|l|}{ Vincoli } \\
\hline C ella & Nome & Valore della cella & Formula & Stato & Tolleranza \\
\hline$\$ C \$ 4$ & Parco 2 Giugno LATITUDINE (Degrees) & 41,10353295 & $C \$ 4>=\$ C \$ 27$ & Non vincolante & 0,005100945 \\
\hline$\$ D \$ 4$ & Parco 2 Giugno LONGITUDINE (Degrees) & 16,865226 & $D \$ 4>=\$ D \$ 27$ & Vincolante & 0 \\
\hline$\$ C \$ 4$ & Parco 2 Giuano LATITUDINE (Dearees) & 41,10353295 & $C \$ 4<=\$ C \$ 28$ & Non vincolante & 0,002885055 \\
\hline$\$ D \$ 4$ & Parco 2 Giugno LONGTUDINE (Degrees) & 16,865226 & $D \$ 4<=\$ D \$ 28$ & Non vincolante & 0,017664 \\
\hline
\end{tabular}

1.6. SPSS ouput regression model on 20 observations in the residential real estate market of Bari using iterative location adjustment factor

Model Summary

\begin{tabular}{|l|l|r|r|r|}
\hline $\begin{array}{l}\text { Mode } \\
\perp\end{array}$ & $\mathrm{R}$ & $\mathrm{R}$ Square & $\begin{array}{c}\text { Adjusted R } \\
\text { Square }\end{array}$ & $\begin{array}{c}\text { Std. Error of } \\
\text { the Estimate }\end{array}$ \\
\hline 1 & $970^{a}$ & 940 & 919 & 18029,096 \\
\hline
\end{tabular}

a. Predictors: (Constant), ILAF, BALCONY, DATE, ELEVATOR, SQM

b. Dependent Variable: PRICE

\begin{tabular}{|rl|r|r|r|r|r|}
\hline \multicolumn{1}{|c|}{ ANOVA $^{\text {b }}$} \\
\hline Madel & & \multicolumn{1}{c|}{$\begin{array}{c}\text { Sum of } \\
\text { Squares }\end{array}$} & \multicolumn{1}{c|}{ df } & Mean Square & \multicolumn{1}{c|}{$F$} & Sig. \\
\hline 1 & Regression & $7,184 \mathrm{E} 10$ & 5 & $1,437 \mathrm{E} 10$ & 44,205 &, $000^{\mathrm{a}}$ \\
& Residual & $4,551 \mathrm{Eg}$ & 14 & $3,250 \mathrm{E} 8$ & & \\
& Total & $7,639 \mathrm{E} 10$ & 19 & & & \\
\hline
\end{tabular}

a. Predictors: (Constant), ILAF, BALCONY, DATE, ELEVATOR, SQM

b. Dependent Variable: PRICE 
Coefficients $^{a}$

\begin{tabular}{|c|c|c|c|c|c|c|}
\hline \multirow{2}{*}{\multicolumn{2}{|c|}{ Madel }} & \multicolumn{2}{|c|}{ Unstandardized Coefficients } & \multirow{2}{*}{$\begin{array}{c}\begin{array}{c}\text { Standardized } \\
\text { Coefficients }\end{array} \\
\text { Beta }\end{array}$} & \multirow[b]{2}{*}{$t$} & \multirow[b]{2}{*}{ Sig. } \\
\hline & & $\mathrm{B}$ & Std. Error & & & \\
\hline \multirow[t]{6}{*}{1} & (Constant) & 52992,393 & 37888,108 & & 1,399 &, 184 \\
\hline & DATE & $-1528,468$ & 305,969 &,- 381 & $-4,995$ &, 000 \\
\hline & ELEVATOR & 36874,737 & 10823,285 & .239 & 3,407 &, 004 \\
\hline & BALCONY & 1763,112 & 630,598 &, 210 & 2,796 & 014 \\
\hline & $\mathrm{SQM}$ & 1495,121 & 251,233 &, 491 & 5,951 & 000 \\
\hline & ILAF & 38093,640 & 11108,496 & 255 & 3,429 & 004 \\
\hline
\end{tabular}

a. Dependent Variable: PRICE

Residuals Statistics ${ }^{a}$

\begin{tabular}{|l|r|r|r|r|r|}
\hline & \multicolumn{1}{|c|}{ Minimum } & Maximum & \multicolumn{1}{c|}{ Mean } & Std. Deviation & \multicolumn{1}{c|}{ N } \\
\hline Predicted Value & 48254,72 & 279685,16 & 136971,35 & 61491,695 & 20 \\
Residual & $-25440,764$ & 26635,277 &, 000 & 15476,088 & 20 \\
Std. Predicted Value & $-1,443$ & 2,321 &, 000 & 1,000 & 20 \\
Std. Residual & $-1,411$ & 1,477 &, 000 &, 858 & 20 \\
\hline
\end{tabular}

a. Dependent Variable: PRICE 